\title{
Süreç Takibi Yöntemi: Nedensellik, Zamansallık, Kuram Geliştirme ve Kuram Testi
}

\author{
Mehtap Söyler*
}

\begin{abstract}
Öz
Tek veya az sayıda vakada, vaka-içi analizle nedensel ve zamansal çıkarım yapmak için uygulanan süreç takibi, nitel araştırmanın temel analitik araçlarındandır. Bu makale, küme kuramına dayalı bir yöntem olarak süreç takibini, çıkarımsal faydalarını, kuram geliştirmek ve nedensel mekanizmaları ortaya çıkararak kuram test etmek için nasıl kullanıldığını inceler. Süreç takibinin işlevlerine nicel ve nitel kültürün nedensellik anlayışındaki farklar aracılığıyla açıklık getirir. Makale, bu yöntemin 'nedenlerin çoğulluğu' sorununa yaklaşımda sunduğu avantajları, karşılaştırmalı siyaset literatüründen örneklerle açıklayarak özgün katkı sunar. Süreç takibi yönteminde Bayesci mantıkla kuram testi tekniklerini Türkiye’nin Irak Savaşı'na katılma kararsızlı̆ı̆, Soğuk Savaş'ın sona ermesi ve Sovyet 'yeni düşüncesi', Türkiye'de yerel seçimler ve kent politikaları üzerine vaka analizlerinden hipotez testleriyle; süreç takibiyle kuram geliştirme stratejilerini, Balkanlar'da Türk azınlığın anayasal kabulü, Doğu Asya'da kalkınmacı devletler, Orta Amerika'da liberalizmin mirasları olan siyasi rejimler üzerine vaka analizi örnekleriyle uygulamalı olarak gösterir.
\end{abstract}

Anahtar Kelimeler: Süreç Takibi, Vaka-içi Analiz, Kuram Geliştirme, Nedensel Mekanizma, Kuram Testi, Bayesci Mantık.

Process Tracing Method: Causality, Temporality, Theory Generation, and Theory Testing

\section{Abstract}

Process tracing is an essential analytical tool for causal and temporal inference in qualitative research. This article examines process tracing as a set theoretic method for within-case analysis, its inferential advantages and application for theory generation, identification of causal mechanisms, and theory testing. It explains the functions of process-tracing by referring to the qualitative and quantitative methodology distinction. It also elucidates the advantages of this method in approaching the issue of 'plurality of causes' by examples from the comparative politics literature, and demonstrates the process-tracing techniques application based on Bayesian logic for theory testing with case studies on Turkey's indecision to participate in the Iraq War, the end of Cold War and Soviet 'new thinking', and local elections and urban politics in Turkey. It illustrates theory development strategies with case studies on the recognition of Turkish minorities in Balkans, the developmental states in East Asia, and the legacies of liberalism in Central America.

Keywords: Process Tracing, Within-Case Analysis, Theory Generation, Causal Mechanism, Theory Testing, Bayesian Logic.

*Dr., Öğr. Üyesi | İzmir Katip Çelebi Üni. i̇.i.B.F. Siyaset Bilimi ve Kamu Yönetimi Böl. mehtap.soyler@ikc.edu.tr | ORÇID: 0000-0003-0243-3240 | DOI: 10.36484/liberal.871546 Liberal Düşünce Dergisi, Yıl: 26, Sayı: 101, Kış 2021, ss. 67- 94. Gönderim Tarihi: 1 Şubat 2021 | Kabul Tarihi: 15 Mart 2021 


\section{Giriş}

Süreç takibi tarihsel olguların nedenlerini açıklamak ve kanıtla temellendirmek olarak tanımlanırsa, aslında binlerce yıldır uygulanmakla birlikte son yıllarda sistemleştirilmeye başlanmış bir yöntemdir. İlk kez 1960’lı yıllarda ABD'de, bilişsel psikoloji disiplininde, bireysel karar verme süreçlerinde rol oynayan mekanizmaların incelenmesi için kullanılmıştır. Süreç takibinin siyaset bilimine transferi 1979'da Alexander L. George'un vaka-içi tarihsel analizlerde birey düzeyinde karar alma mekanizmalarını analiziyle gerçekleşmiştir (George, 1979). Bu yöntem günümüzde tek vaka çalışmalarında ya da az sayıda vakanın karşılaştırmasında vaka-içi analizle nedensel çıkarımların geliştirilmesi için kullanılır. Genellikle, tarihsel bir açıklama yaparken sonucun nedenlerini tespit etmek, bir vakada olayların ardışıklığını (sequence) incelemek için başvurulan yöntemdir (Bennett ve Checkel, 2015; Collier vd., 2010; George ve Bennett, 2005). Süreç takibi bir vakadaki "mekanizmaların gözlemsel vaka-içi etkilerini belirlemek veya teyit etmek amacıyla uygulanan çalışma prosedürüdür." (George ve Bennett, 2005: 138) Etkilerin belirlenmesi kuram geliştirmeye ve teyit edilmesi kuram testine imkân sağlar.

Nitel araştırmada süreç takibi yöntemi, tek ya da az sayıda vakada vaka-içi analizle nedenselliği ve zamansallığı inceler. Bu yüzden, süreç takibi aynı zamanda sosyal bilimlerde nedensellik ve zamansallık üzerine düşünmemizi sağlar. Nedensellik, yani neden ve sonuç arasındaki ilişkinin niteliği üzerine düşünmek felsefenin ve bilimin kadim meselesidir. İnsan bilinci nedenselliği kavrayamasaydı, ne evrenin doğasına dair yasaları anlayabilirdi, ne öz bilinçle ahlaki sorumluluğun farkına varabilirdi, ne de hukuk mümkün olabilirdi. Aristoteles'ten Farabi'ye, Biruni'den Isaac Newton'a, David Hume'dan John Stuart Mill'e, Hans-Georg Gadamer'in yorum yönteminden Michel Foucault'nun bilginin arkeolojisine -farklı varsayımlara dayansa da- nedensel ilişkiler hakkında tartışma düşünsel ve bilimsel gelişimin temeli olmuştur (Mumford ve Anjum, 2013). Sosyal bilimlerde nedensellik doğa bilimlerinden farklı olarak doğrudan gözlemlenemez. Doğa bilimlerinde de, örneğin astronomide belli gözlem araçları (teleskop, uydu vb.) olmadan gözlem mümkün değildir; orada dahi, gelişen teknolojiye rağmen, gözlemlemenin mümkün olmadığı, insan yetilerinin sınırını belirleyen bir ufuk çizgisi bulunur. Bu sınırlılık yüzünden nedensel çıkarım yapılır, belli nedensellik anlayışlarına dayanarak nedensonuç ilişkileri hipotezler halinde ifade edilir. Demokrasi kuramları, demokrasiye yol açan şartlara dair (örneğin ekonomik gelişme, siyasi kültür, sosyal sermaye, vb.) çeşitli hipotezler öne sürer. Hipotezlerin gözlemlenebilir ve test edilebilir belirtileri ya da ipuçları vardır. Nedenselliğin kendisini doğrudan 
gözlemleyemeyiz, ama belirtileri veya ipuçlarını gözlemleyebiliriz (Bennett ve Checkel, 2015: 11-12).

Nedenselliğin var olup olmadığı ya da ne olduğu sorusu metafiziğin bir sorusudur. Metafiziksel bir tartışma bu makalenin amacını aşacağından, bu girişin amacı, nedenselliğin epistemolojisine, yani nedensellik anlayışlarındaki farklılıklara açıklık getirmektir. Sosyal bilimlerde ampirik ve kuramsal boyut birbirine bağlıdır. Ampirik boyut, önemli olguların (örneğin savaş, kapitalizm, devlet, demokrasi, siyasi kültür, temsil, vb.) zaman ve mekân bağlamında olaylar ve nedensel süreçlerin toplamı olmasıdır; kuramsal boyut, bunların aynı zamanda zihinsel ve toplumsal bir inşanın ürünü olan soyut kavramlar olmasıdır. Bu olayların ne olduğuna ve neden olduğuna dair ontolojik sorular bizi kavram ve kuramlara götürür. Epistemolojik soru ise bilgiye ulaşma yoluyla, nedensel çıkarımın nasıl yapıldığıyla ilgili sorulardır (Brady, 2008: 224-225). Örneğin, “demokrasinin hayatta kalmasını sağlayan neden(ler)i nasıl bilirim?” veya “ekonomik gelişmenin demokrasinin hayatta kalmasına neden olup olmadığını nasıl bilirim?” gibi epistemolojik sorular nedensellik anlayışı hakkındadır.

Sosyal bilimlerde nicel ve nitel kültür nedensellik anlayışları kullandıkları mantık bakımından farklılaşır. Nicel kültürün temel mantığı David Hume ([1748] 2004) tarafından tanımlanan korelasyonun 'daimî bir aradalığı' (constant conjunction) prensibine, yani nedenin olduğu yerde onu her zaman sonucun takip etmesi varsayımına dayanır. ${ }^{1}$ İstatistiksel testler çok sayıda vakada neden ve sonuç arasındaki ilişkiyi olasılıksal mantıkla vakalar-arası (cross-case) karşılaştırmaya tabi tutar. Fakat, yönteme giriş derslerinde sahte ilişkileri (spurious relations) tanımlarken verilen leylekler ile doğum oranları arasındaki korelasyon örneğinden anımsanacağı gibi korelasyon ve nedensellik aynı şey değildir. İstatistiksel bulgular darbeler ile otokrasi ya da demokrasi ile ekonomik gelişme arasında olasılıksal birlikteliği (probabilistic association), bir arada olma olasılığını, teyit ettiğinde sahte ilişkilere dair soru ortadan tamamen kalkmaz; tartışma, temelde nedensellik üzerinedir. Standart istatistiksel araçların işlevi belli bir vakada neden(ler)in sonuca nasıl götürdüğüne dair nedensel mekanizmalar hakkında hipotez geliştirmek olmadığından, güçlü hipotezleri genellikle deneysel yöntem üzerinden elde etmeye çalışırlar (Goertz ve Mahoney, 2012: 100-103).

1 Günümüzde ana akım istatistiksel yaklaşım karşı-olgusal (counterfactual) nedensellik anlayışına dayalı Neyman-Rubin-Holland modeli ve potansiyel sonuçlar çerçevesini (potential outcomes framework) benimsemiştir (bkz. Sekhon, 2010), fakat bu çerçevenin varsayımsal temelinde Hume'un tanımı vardır (Goertz ve Mahoney, 2012: 78). Nitel ve nicel kültür farkını değerlendiren, küme kuramı ve matematiksel mantığa dayalı nitel yöntemi tanıtan uygulamalı bir rehber için bkz. Söyler, $2020 b$. 
Nitel kültür, kökleri Aristoteles'e uzanan matematiksel mantık uyarınca, nedenselliği gerekli ve yeterli şartlar üzerinden, 'belirlenimci’ bir anlayışla, düşünür. Bağımlı değişkenin düzeyinin bağımsız değişkenin düzeyiyle ortalama olarak yükseldiği veya düştüğüne dair hipotezlerde olasılıksal ilişki bulunur (Goertz ve Mahoney, 2012: 18). Ekonomik gelişmenin demokrasiye içsel (endogenous) olduğuna dair Seymour Martin Lipset'in -modernleşme kuramlarının klasiği olmuş- hipotezi, bir ulus ne kadar zenginse demokratikleşme şansının o kadar yüksek olduğudur (1959: 75) Hume'un tanımını nitel mantık veya küme kuramıyla okuyalım. Nedenin olduğu yerde onu daima sonucun takip etmesi nedenin sonuç için bir yeter-şart olduğu anlamına gelir. Ekonomik gelişmenin olduğu yerde daima demokrasinin olması, onun demokrasi için yeterli neden olduğu anlamına gelir. Fakat, onun tek neden olmadığı, başka nedenlerin de yeterli olabileceği sonucu çıkar. Öte yandan hipotezin alternatif okuması, ekonomik gelişme olmadan, yoksulluk ve sefalet sona ermeden demokratikleşmenin mümkün olmadığıdır. Ekonomik gelişme olmadan demokrasi olmuyorsa, neden ve sonuç arasında gereklilik ilişkisi mevcuttur. Gerek-şart, tüm demokrasilerde ekonomik gelişmenin de teyidini gerektirir. Küme kuramına göre, ekonomik gelişme demokrasinin yeter-şartı ise, ekonomik gelişme demokrasinin bir alt kümesidir; ekonomik gelişme demokrasinin gerek-şartı ise, demokrasi ekonomik gelişmenin bir alt kümesidir (Goertz ve Mahoney, 2012: 16-25).

Sosyal olgularda tarihselliği, nedensellikte zaman boyutunu düşünmek, nedenselliğin yönü üzerine düşünmeye sevk eder. Demokratik kurumların oluşmasına yol açan sosyal koşulların kişi başına düşen gelir, sanayileşme ve eğitim düzeyiyle ölçülen ekonomik gelişme olduğunu iddia eden 'Lipset hipotezi' bugüne dek çok tartışılmıştır. Bu hipotezi revize eden bir vakalar-arası zaman serisi analizi (1950-1990), ekonomik gelişmenin demokrasiye geçişe neden olmadığını, ancak demokrasi tesis edildikten sonra rejimin istikrarına neden olduğunu öne sürer (Przeworski vd., 2000). Bu hipoteze karşılık, Avrupa'da 19. yüzyıl ortalarından 2. Dünya Savaşı'na kadar demokratik kurumların gelişiminin inceleyen bir çalışma, ekonomik gelişmenin demokrasiye geçiş olasılığını artırdığını iddia etmiştir (Boix ve Stokes, 2003). Bir vakalar-arası zaman serisi analizi (1972-1989) ekonomik gelişme düzeyinin demokrasiye neden olduğunu teyit etmekle birlikte, demokrasinin ekonomik gelişmeye neden olmadığını, nedenselliğin çift yönlü işlemediğini tespit etmiştir (Burkhart ve Lewis-Beck, 1994). Bu hipoteze karşılık başka bir çalışma, 1960-2010 yılları arasında 175 ülkenin verilerini inceleyerek, nedenselliğin yönünün demokrasiden ekonomik gelişmeye de gittiğini ileri sürmüştür. Demokrasiye geçmiş bir ülkedeki kişi başına düşen gayrı safi yurt içi hasıla, 25 
yıl içinde, demokratik olmayan bir ülkeninkine göre \%20 daha fazladır (Acemoğlu vd., 2019).

Sosyal bilimlerde kaçınılmaz olarak karşımıza çıkan karmaşık ve çok boyutlu olgular tek bir nedenle açıklanamaz. Mill'in 'nedenlerin çoğulluğu' ( [1843] 1973) olarak tanımladığı bu sorun nicel yöntemde ve nitel yöntemde farklı ele alınır. Nedenlerin çoğulluğu nitel yöntemde iki terimle ifade edilir: birleşik nedensellik (conjunctural causation) ve eş-sonuçluluk (equifinality). Birleşik nedensellik, birden çok gerekli ve yeterli koşulun birleşerek nedensel dizilim oluşturmasıdır. Birden fazla neden birleşerek bir 'nedenler paketi' halinde sonuca götürür. Eş-sonuçluluk, birden çok nedenin veya nedensel dizilimin aynı sonuç için yeterli olmasıdır. Süreç takibiyle, nedenlerin çoğulluğunu içinde barındıran nedensel mekanizmaları tek ya da az sayıda vakada vaka-içi analizle ortaya çıkarmak mümkündür (Goertz ve Mahoney, 2012: 7582, 100-110; Ragin, 1987). Mill'in farklılık ve uyuşma yöntemleri eş-sonuçluluk ihtimalini göz önünde bulundurmamaktadır. Süreç takibi eş-sonuçluluğu göz önünde bulundurur, dolayısıyla eş-sonuçluluğun göz ardı edilmesinden kaynaklanan nedensel çıkarım hatalarını önleme imkanı sunar (George ve Bennett, 2005: 153-160).

Nicel kültürde çok değişkenli istatistiksel analizde amaç tekil değişkenlerin sonuca ortalama etkisini incelemektir. Karmaşık nedensellik örgülerinin tespiti, değişkenlerin nedensel etkilerinin araştırma evreninden tekil vakaya inerken sabit olmaması, etkinin daima olumsal (contingent) olması nedeniyle istatistiksel modelde yöntemsel sorunları beraberinde getirir (Braumoeller, 2003, 2004). Buna karşın, nitel kültür nedenler paketi içindeki tekil nedenlere odaklanmaz, nedenlerin birleşimi tekil nedenlerden daha önemlidir. Küme kuramsal hipotezlerde belli nedenlerin birleşimi vardır. Demokrasiye A, B, $C$ nedenlerinin birleşimi neden olmuşsa, ampirik olarak bir vakanın nedenler paketindeki her etken kümesine üye olması durumunda sonuç kümesine de üye olduğu çıkarımı yapılır. Nedenler paketi sonuç için yeterli ise paket içindeki tekil nedenler ya gerek-şarttır ya da INUS şarttır; ${ }^{2}$ INUS şartta, aynı sonuca götürmekte yeterli olan birden çok nedensel birleşim vardır (Ragin, 1987; aktaran Goertz ve Mahoney, 2012: 24-25, 57-58).

Neden ve sonuç arasındaki 'kara kutu' ancak gelişmiş kuramlara dayanan ampirik analizle, zamansallığı göz önünde bulunduran nitel, tarihsel vaka analizleriyle tam olarak açılabilir (Rueschemeyer vd., 1992: 4). Süreç takibi

2 INUS (Insufficient but Necessary part of a condition which is itself Unnecesssary but Sufficient for the result): Sonuç için gerekli değil ama yeterli olan bir şartın yeterli olmayan ama gerekli bir parçası (Mackie, 1965: 246). 
tarihi arşiv belgeleri, mülakatlar, demeçler, biyografi ve hatıralar, mektuplar, güncel haberler kullanarak hangi süreçsel nedenlerin sonuca götürdüğünü betimlemek veya açıklamakta bize yardımcı olur. Aşırı yoksulluk ve baskıya maruz kalan, en güçsüz gruplar arasında sayılan mültecilerin ne zaman isyan ettiğini soran Clarke (2018), Türkiye, Lübnan ve Ürdün'ü vaka-içi analizle karşılaştırmıştır. Bu mülksüz ve yurtsuz grupların Ürdün'de neden ve nasıl özerk bir siyasi güç kazanıp hizmetlerin iyileştirilmesi ve hak mücadelesi için seferber olduklarını sormuştur. İnsani yardım kurumlarının belgelerini, kamplarda meydana gelen olaylara dair verileri ve kamplarda yaptığı 87 mülakatı kullanmıştır. Mülteci kamplarının Ürdün'de dar mekânsal alanda yoğunlaşması ve mülteci yönetiminin parçalanmış olması mültecilerin güçlü liderlik ağları kurmalarına neden olmuştur. İki gerek-şart birleşerek mültecilerin siyasi amaçlar için seferberliğine götüren neden paketini oluşturur. Bu iki şartın birleşimi tekil etkilerden daha büyük bir etkiye sahiptir. Eğer mültecilerin siyasi seferberliğini açlklayan başka bir neden ya da nedenler paketi olsaydı, nedenler birleşimindeki tekil şartlar INUS şart olurdu.

Nicel yöntemle vakalar-arası karşılaştırmada istatistiksel prensip 'birim homojenliği', bağımsız değişkendeki değer değişikliğinin tüm vakalarda bağımlı değişkende aynı derecede değişiklik yaratacağı varsayımıdır. Nitel yöntemde vakalar-arası karşılaştırmada nedensel heterojenlik, belli bir zaman süresinde gözlemlenen aynı değerde etkenlerin sonuca etkisinin yön ve derecesinin vakadan vakaya farklılaşabilmesidir. Nedensel heterojenliğin bir başka türü, aynı etkenin farklı tarihsel kesitlerde farklı sonuçlara götürebilmesidir. Zamansal değişimi sadece genel olarak vakalar-arası değil, vaka-içinde de düşünürsek, zaman boyutunun etkisi daha belirgin hale gelir. Nitel yöntemin neden ve sonuç arasındaki “kara kutuyu” açmasının nedeni, zaman boyutunu ekleyerek, yapı-yapan ilişkisinde yapısal faktörlerden mikro düzeye gidebilmesi; böylece, aktörlerin tercihlerinin ve kurumlar içinde aldıkları pozisyonların, aktörlerin birbiriyle ve yapıyla nasıl etkileşime girdiğinin analiz edilmesidir. Ayrıca, nedenselliğin yönü incelenirken, Lipset hipotezinden verilen örneklerde olduğu gibi tek yönlü ilişkiler değil döngüsel nedensellik (circular causality) de incelenebilir. Tarihsel kurumsalcı yaklaşımla izlek bağımlılığını (path dependency) araştırmak, tavuk-yumurta ilişkisindeki gibi döngüsel nedenselliği sistematik bir analize tabi tutar (Capoccia ve Ziblatt, 2010: 935-939; Munck ve Snyder, 2007: 23). Başka bir deyişle, belli standartlara uyulursa, süreç takibi nicel yöntemin sağlayamadığı çıkarımsal kazanımlar sağlar (Collier, 2011).

$\mathrm{Bu}$ makale, küme kuramına dayanan belirlenimci nedensellik anlayışı çerçevesinde süreç takibi yöntemini, sunduğu çıkarımsal faydaları, kuram 
geliştirmek ve nedensel mekanizmaları ortaya çıkararak kuram test etmek amacıyla nasıl kullanıldığını inceler. ${ }^{3}$ Tek veya az sayıda vakada vaka-içi analiz yöntemi olan süreç takibi nasıl uygulanır? Bu yöntem nedensel çıkarımları nasıl destekler? Süreç takibi yöntemiyle kuram geliştirmek ve test etmek için hangi teknikler kullanılır? Vaka analizinde alternatif hipotezlerin sağlamllğını hangi kriterlere göre karşılaştırabiliriz? Makale, bu soruları yanıtlamak için ilk olarak, vaka, vakalar-arası analiz ve vaka-içi analiz terimlerini açıklar; nedensellik anlayışlarından kaynaklı gözlem farkına değinir. İkinci olarak, küme kuramıyla nedensel ve zamansal analiz tekniklerini tanıtır. Üçüncü olarak, kuram geliştirme ve Bayesci mantık aracılığıyla kuram testini izah eder. Bu çalışmanın özgün katkısı, süreç takibinin 'nedenlerin çoğulluğu' sorununa eğilirken sunduğu avantajları, nedensel ve zamansal analiz tekniklerini, kuram geliştirme ve kuram testini karşılaştırmalı siyaset literatüründen örneklerle uygulamalı olarak göstermesidir.

Makale, süreç takibinin çıkarımsal avantajlarını, karşılaştırmalı siyaset literatüründen ekonomik gelişme ve demokrasi, liberalizm ve siyasi rejimler, liberalizm ve Soğuk Savaş'ın sona ermesi, silahlı çatışmaya demokratik katılım, mültecilerin siyasi seferberliği konularına dair çalışmalardan örneklerle açıklar. Süreç takibi yönteminde Bayesci mantıkla kuram testi tekniklerini Türkiye'nin Irak Savaşı'na katılma kararsızlığı, Soğuk Savaş'ın sona ermesi ve Sovyet 'yeni düşüncesi', Türkiye'de yerel seçimler ve kent politikaları üzerine vaka analizlerinden hipotez testleriyle; süreç takibiyle kuram geliştirme stratejilerini, Balkanlar'da Türk azınlığın anayasal kabulü, Doğu Asya’da kalkınmacı devletler (developmental states), Orta Amerika'da liberalizmin mirasları olan siyasi rejimler üzerine vaka analizleriyle uygulamalı olarak gösterir. Web of Science (WoS) Siyaset Bilimi kategorisindeki dergilerde yayınlanan Türkiye adresli makalelerin çoğunlukla vaka analizlerinden oluştuğunu ve Türkiye odaklı olduğunu tespit etmiştir (Cansun ve Arık, 2019: 867, 870; İşeri ve Esentürk, 2016: 27). Çalışma, süreç takibi yöntemini incelemek suretiyle, bu analitik aracın faydalarından yararlanılmasına, dolayısıyla vaka analizlerinin kuramsal etkisinin belirginleştirilmesine ve artırılmasına katkıda bulunmayı hedefler. ${ }^{4}$

3 Bu yöntemin nicel kültürde, olasılıkçı nedensellik anlayışı çerçevesinde de uygulanması mümkündür.

4 Türkiye çalışmalarında vaka analizi ile kuramsal katkı üzerine öneriler sunan başka bir çalışma için bkz. Somer, 2014. 


\section{Nedensellik ve Gözlem: Vaka, Vakalar-arası Yöntem ve Vaka-içi Analiz}

Sosyal bilimlerde vaka "bir birimin daha geniş benzer bir birim sınıfını anlamak için incelenmesidir" (Gerring, 2004: 342); dolayısıyla, vaka ve vaka seçimi nitel ve nicel araştırmanın ortak terimleridir. Vakalar-arası karşılaştırma için uygulanan yöntemler çok değişkenli istatistiksel analizler, Mill'in farklılık ve benzerlik yöntemlerine dayanan nitel vaka analizi ile karşılaştırmalı nitel analizdir (qualitative comparative analysis, QCA); vaka-içi analizde ise en gelişmiş yöntem süreç takibidir. Bu bölüm ilk olarak, vaka, vaka analizi, vakalar-arası analiz, vaka-içi analiz terimleri arasındaki farka değinir. İkinci olarak, süreç takibi yöntemini nitel bir analitik araç olarak kavrayabilmek için nedensel süreç gözlemleri ile nicel yöntemin dayandığı veri seti gözlemleri karşılaştırır. Son olarak, süreç takibine değişken odaklı yaklaşımı bu makalede benimsenen olay odaklı yaklaşımla karşılaştırır.

Araştırma evreni, örneklem, birim, vaka ve gözlem semantik alanda komşu terimlerdir. Araştırma evreni araştırılmış ya da araştırılacak vakalardan ve araştırılmamış vakalardan oluşur. Örneklem içinde birimler ülke, devlet, siyasi rejimler, toplumsal hareketler, siyasi parti, liderler, seçmenler örneklerinde olduğu gibi farklı analiz düzeylerine ve süreçlere karşılık gelebilir. Bir birim tek vaka ya da birden çok vakayı kapsar. Birim(ler)in mekânda ve/veya zaman bağlamında gözlemlenmesi vakayı/vakaları meydana getirir. Altını çizmek gerekirse, bu terimler iç içe geçmiştir. Araştırma kurgusuna göre, evrenin, birimin veya vakanın ne olacağı değişebilir. Örneğin, istatistiksel bir araştırmada demokrasiyle yönetilen tüm ülkeler evren olup, bu siyasi rejim biriminde olduğu tespit edilen ülkelere dair gözlemler vakaları oluşturur; diğer araştırmada ise aynı evren tanımlanıp, Türkiye'de siyasi liderler birim olup, vakalar tekil liderlere dair belli yılları kapsayan gözlemler olabilir; vakalar-arası ve vaka-içi analizi birleştiren bir nitel araştırmada, birim siyasi rejimler olup karşılaştırılan vakalar arasında Türkiye'de siyasi rejimlerin tarihsel gelişimi gözlemlenebilir ve vaka-içi analizde kuramsal gerekçeler belirtilerek tüm vakalarda gözlemler demokratikleşme öncesi/sonrası olarak dönemlere ayrılabilir. Evren, örneklem, birim ve vakaya dair önermelerin netleşmesi çalışmanın çıkarımlarının belirginleşmesi ve yanlışlanabilirliği açısından önemlidir (Gerring, 2004, 341-354).

Süreç takibini anlamak için nicel ve nitel kültürün çıkarım yapma yolu ve amacındaki farklara değinmek gereklidir. Nicel araştırma veri seti gözlemlerine; nitel araştırma süreç takibi nedensel süreç gözlemlerine dayanır. Vaka, hakkında çıkarım yapılan, veri toplanan biriminin örneğidir. Vaka hakkında 
çıkarım yapılacak birim(ler)in gözlemlenmesidir, aynı zamanda neyin nasıl gözlemlendiğiyle ilgilidir. Vaka sayısı teamülen S harfi ile kısaltılır. Standart nicel/istatistiksel analizlerde kullanılan dikdörtgen veri setleri, genellikle çok-S analizde her vaka için tek satırda farklı değişkenlere dair gözlemler içerir. Veri setindeki her satır birer vakadır, sütunlar değişkendir, hücre ise gözlemdir. Nedensel süreç gözlemleri ise, genellikle tek vaka veya az-S analizde her vakaya dair bağlam, süreç ve mekanizmalara dair veri ya da bilgidir (Collier vd., 2010: 182-186; Hall, 2003: 391-394; Ragin, 1992: 1-17). ${ }^{5}$

Çok değişkenli istatistiksel yöntemler bağımsız değişkenlerin bağımlı değişken üzerindeki ortalama etkilerini sayısal olarak hesaplar. Sonuç raporunda bulgular, tüm vakalarda bağımsız değişkenlere dair veriler hesaplanarak elde edilen, bağımsız değişkenlerin bağımlı değişken üzerinde ortalama etkilerine dair toplam sonuçlardır. Ortalama nedensel etkilerin incelenen vakalarda birbirinden ayrı gözlemlenebileceği ve ölçülebileceği varsayımına dayanır. Nicel yöntemde asıl amaç tekil vakaları açıklamak değildir, amaç nedenlerden sonuca giderek nedenlerin ortalama etkisine dair çıkarımları evrene genellemektir. Buna karşın nitel araştırma, evrene genelleme yapmayı değil, tekil vakaları açıklamayı amaçlar. Nitel kültürde süreç takibi tekil vakalar içinde nedenlerin birleşimine, sürece ve nedensel mekanizmalara odaklanır (Goertz ve Mahoney, 2012: 42-48; Hall, 2008: 306). Burada, süreç veya süreç takibinin her zaman mekanizma içermeyeceği eklenmelidir. Süreç takibinin işlevi betimleyici ve/veya açıklayıcı çıkarımlar yapmak, kuram geliştirmek ve kuram testi yapmaktır. Nedensel çıkarımlar yapmak ve nedensel çıkarımları test etmek mekanizmalar olmadan yapılamaz. Fakat, betimleyici çıkarımlardan oluşan hipotezlerin süreç takibi testleri mekanizmaların incelenmesini gerektirmez. Ayrıca, süreç takibi yöntemi kuram geliştirmede kullanıldığında zorunlu olarak mekanizma tespiti yapmaz (Mahoney, 2012).

Veri-seti gözlemlerine örnek olarak, Lipset hipotezini revize eden bir istatistiksel vakalar-arası zaman serisi analizde (Przeworski vd., 2000) ülkeler birimdir, vakalar 135 ülkenin 1972-1989 yılları arasında yıl bazında pek çok değişkene (siyasi rejim, nüfus, gelir, vb.) dair gözlemlerini içerir. Bulgulara göre, ekonomik gelişme demokrasiye geçişi sağlamaz, demokratik bir ülkede siyasi rejimin istikrarını sağlar; siyasi rejimler ekonomiden çok nüfusa etki eder. Demokrasilerde kişi başına düşen gelirin daha hızlı yükseldiği, diktatörlüklerde nüfusun daha hızlı artmasıyla gelirin de düştüğü, siyasi istikrarsızlığın sadece diktatörlüklerde ekonomiye olumsuz etkide bulunduğu gözlemlenmiştir.

5 Karşılaştırmalı nitel analizde (QCA) genelde orta-S analiz yapılmaktadır. 
Sonuçlar bağımsız değişkenlerin tüm vakalarda ortalama etkilerine dair toplam sonuçlardır ve genelleme araştırma evrenine yapılmaktadır.

Başka bir veri seti gözleminde Mainwaring ve Pérez-Liñán (2013: 93-123), 1945 ve 2005 yılları arasında Latin Amerika'da rejim değişikliğini, özellikle 1977'den sonra otoriter rejimlerden demokrasiye geçişleri ve demokrasinin çöküşünü incelemiştir. İstatistiksel analiz, bir ülkede demokrasiye geçiş olasılığını komşu ülkelerde bu tür geçişin yaşanmış olması ile siyasi aktörlerin tercihlerinin artırdığını ortaya koymuştur. Ekonomik gelişme gibi yapısal faktörler rejim değişimini tahmin etmede zayıf kalmıştır. Diktatörlüklerde muhalif aktörlerin radikalleşmesinin rejimin çökmesine ve rekabete dayalı siyasete geçilmesine (ortalama) etkisi yüksektir. Demokrasiye geçişten sonra demokrasinin hayatta kalma olasılığını artıran, komşu ülkelerde bu tür geçişin yaşanmış olması ve siyasi aktörlerin rekabete dayalı siyaseti normatif bir tercih olarak görmeleridir. Demokrasiye geçişten sonra, radikal siyasi aktörlerin varlığ1 demokrasiye normatif bağlılığ1 zayıflatarak olumsuz etkide bulunmuştur.

Süreç takibi yöntemine değişken odaklı yaklaşım bu yöntemin çıkarımsal faydalarının yanlış değerlendirilmesine neden olmuştur. King, Keohane ve Verba, süreç takibini bağımlı ve bağımsız değişkenleri birbirine bağlayan 'müdahil değişkenlerin' (intervening variables) incelenmesi olarak görmüştür. Süreç takibini, bağımsız değişkenlerin nedensel etkilerini tahmin ederken $\mathrm{X}$ bağımsız değişkeni ile $\mathrm{Y}$ sonucu arasındaki $\mathrm{M}$ müdahil değişkeni $(\mathrm{X} \rightarrow \mathrm{M} \rightarrow \mathrm{Y})$ bulmaya yarayan bir araç olarak değerlendirmişlerdir. Sosyal bilimlerde süreci takip ederken makro ölçekten mikro ölçeğe gitmek gerekir. Nedenler birden çok ve karmaşıktır; her müdahil değişkene neden olan zamansal olarak önceki müdahil değişkene gitmek mümkündür. King, Keohane ve Verba, açlklanan ve açıklayıcı değişkenler arasında sonsuz müdahil değişkenin mümkün olacağını, dolayısıyla sonuçtan nedene doğru giderken sonsuz müdahil değişkenle geriye gitmeye (infinite regress) yol açacağını öne sürmüşlerdir. $\mathrm{Bu}$ yaklaşımla, süreç takibi nedensel çıkarım yapamaz; ancak betimleyici genellemeler yapmayı sağlayarak, dolaylı olarak nedensel çıkarımları destekleyebilir (King vd., 1994: 227-228).

Oysa, süreç takibinde vaka "olaylar sınıfının örneğidir" (George ve Bennett, 2005: 17). Olaylar tümevarım yoluyla ardışıklıkların ve daha büyük bir sürecin parçası olarak incelenir. Vaka analizinde sonuç genellikle, demokrasiye geçiş gibi, açıklanması beklenen makro düzeyde olgudur. Savaş, barış, demokratikleşme, darbe, küreselleşme bir olaylar sınıfıdır; gözlemlenen bu olaylar sınıfının kavramsallaştırılması sonucu soyut kategoriler haline 
gelmişlerdir. ${ }^{6} \mathrm{X} \rightarrow \mathrm{M} \rightarrow \mathrm{Y}$ nedensel çizgesinde, mekanizma müdahil değişkenler değil, olaylardır. Değişken olarak düşünecek olursak, değişkenin belli bir değerine karşılık gelmesi itibariyle belirlenmiştir. 'Müdahil olaylar' küme kuramıyla düşünülür. Bir vaka belli olaylar kümesine üye midir? Olaylar, kendisi de bir küme olan vakaların ait olduğu kategorilerdir. Olaylar vakaların kümelere üyeliğini temsil eder, değişkenler ise vakaların özellikleridir. Değişken odaklı soru, bir vakanın bir özelliği taşıyıp taşımadığı ya da ne derece taşıdığına yöneliktir. Olay odaklı soru, belli bir vakanın söz konusu olay kümesine üyeliğinin olup olmadığı, ya da ne derece üye olduğuna yöneliktir (Mahoney, 2016: 494-495).

Tüm ardışıklık analizleri her olayın etken olarak nedensellikteki rolünü tanımlarken etkenin süresini, sırasını ve hızını dikkate alır. Örneğin, yerel seçimler ve uluslararası ticaret anlaşmaları farklı analiz birimlerine karşılık gelen olaylardır; bir ülkede kanun değişikliği veya yeni anayasanın ilanı veya iklim değişikliği meydana geliş veya etki süreleri bakımından farklıdır; darbe ile devrimin neden oldukları değişimin kapsamı aynı olmayabilir. Olayları farklı analiz birimlerine, oluşma ya da etki sürelerine, ne ölçüde değişime neden olduklarına göre sınıflandırabiliriz. Bağlam, olayların hem zamansal ya da mekânsal arka planı oluşturur hem olayların hangi sonuçlara götüreceklerini etkiler. Ardışıklık, belli bir bağlamdaki olayların belli bir sırayla birbirini takip etmesidir. Süreç, zamansal ardışıklığa tabi olayların birbiriyle bağlı ve tutarlı bir bütün oluşturarak, yeniden üretici ya da dönüştürücü bir etki yapmasidır (Mahoney ve Falleti, 2015: 212-215).

Olaylar genel özellikleri itibariyle tekrar edebilir ve karşılaştırılabilir; tarihsel olaylar, örneğin Amerika Birleşik Devletleri'ne 11 Eylül 2001'de gerçekleştirilen terör saldırıları, tekrarlanamaz. Tarihsel vaka analizlerinde belli olaylar, örneğin Türkiye’nin 1950'de Kore Savaşı'na asker göndermesi betimlenebilir. Bu olay analitik anlamda uluslararası askeri müdahaleler kümesine dahildir. Bir araştırmada olaylar farklı analitik ağırlıkları olan etkenler olarak görülürse yeni araştırma soruları, yeni bulmacalar keşfedilebilir. Örneğin, gözlemlenen olguyu Türkiye’nin katıldığı ya da katılmadığı uluslararası askeri müdahaleler çerçevesinde karşılaştırma imkânı doğar. Soğuk Savaş bağlamında ABD öncülüğünde Birleşmiş Milletler müdahalesine katılan Türkiye, Soğuk Savaş sonrası dönemde 1991'de Irak’a karşı uluslararası koalisyona katılmış, 1 Mart 2003’te ise Irak Savaşı'na asker gönderme ve ülke içinde

6 Bu yüzden, araştırma evreni ve örneklem veya vaka seçimi çoğunlukla tartışma yaratır. Araştırma kurgusunda vaka seçiminden ve ölçümden önce kavramsallaştırma gelir (Sartori, 1970: 10361040). Sartori geleneğinde kavram ve kuram analizi yöntemini tanıtan uygulamalı bir rehber için bkz. Söyler, 2020a. 
yabancı asker konuşlandırmaya dair tezkere mecliste reddedilmiştir. Olayları etken olarak zaman ve mekân bağlamıyla düşünmek süreç takibi soruları sormak için iyi bir başlangıçtır.

Süreç takibi tek ya da az-S vaka analizinde ardışıklığın sistematik analizidir. Şu temel soruyla ilgilenir: “Z vakasında Y'ye neden olan X'ler nelerdir?” M bir olaydır ya da bir değişkenin belli bir değeri olması itibariyle belirlenmiştir, tıpkı neden ve sonuçlar gibi. $\mathrm{X} \rightarrow \mathrm{M} \rightarrow \mathrm{Y}$ nedensel çizgesinde M’nin (mekanizmanın) farkı zamansal olarak neden ve sonuç arasında olmasıdır. Bu sorudan iki süreç takibi sorusu çıkar: “ $Z$ vakasında Y’ye götüren olası nedenler ya da alternatif açıklamalar nelerdir?”, “Z vakasında belli X'ler mi Y'ye sebep oldu?" İlk soruyu araştırmak kuram geliştirmeye, ikinci soruyu araştırmak kuram testine yarar (Mahoney, 2015: 201, 206). 1 Mart 2003'te TBMM’nin aldığı ret kararına götüren süreci takip eden Taydaş ve Özdamar (2013) hükümetin bölünmüşlüğü, meclisin Müslüman bir ülkeye müdahaleyi ideolojik anlamda savunamaması ve başbakanın güçlü bir irade ortaya koyamamasının birleşerek tezkerenin reddine yol açtığını tespit eder.

Nedensel mekanizma ya da nedensel zincirler nedeni sonuca bağlayan etkenlerdir. Süreç takibinde, zamansal anlamda neden ve sonuç arasında konumlanan, farklı zaman dilimlerinde ortaya çıkan ardışık öğeler ya da olaylar serisinin, yani nedenler zincirinin sonuca götürmesi ele alınır (George ve Bennett, 2005: 206). Mekanizmalar üç farklı şekilde tanımlanabilir: neden ve sonuç arasına giren müdahil olay, sonuca yol açan etkenlerin belli nitelikleri, genel süreçler veya kuramsal prensipler (Mahoney, 2015: 206).7 Mekanizmalar sadece gözlemlenebilen sosyal ya da fiziksel bir olay olmak zorunda değildir; kuramların hipotezleri ya da sosyal ve psikolojik süreçler, yani gözlemlenemeyen ama gözlemlenebilir ve test edilebilir sonuçları olan ontolojik birimler olabilir. Sonuca götüren olayları teşhis etmeye yardım eden kanıt görevi görürler. Bağımlı değişken üzerinde herhangi bir bağımsız etkide bulunmazlar. Eğer bunlar bağımsız değişkenlerin bir parçası değil de bağım1 değişkeni doğrudan etkiliyorsa geliştirilen kurama bir bağımsız değişken olarak eklenebilir (Bennett ve Checkel, 2015: 6-7, 12).

7 Waldner (2015) burada sunulan yaklaşıma alternatif tümdengelimsel bir yaklaşımla, mekanizmaların 'kuramsal mekanizmalar', yani güç, sistemsel etkiler (yayılma, itme ve çekme kuvveti, vb.) gibi bir değişkenin başka bir değişkeni etkilemesini sağlayan genel süreçler ya da kuramsal prensipler, soyut etkileme özelliği olduğunu ileri sürer. Waldner'e göre, mekanizmalar değişken değildir; kuramların hipotezlerinde yer alan değişkenlerin sabit değerleridir. $X \rightarrow M \rightarrow Y$ çizgesinde okların neden var olduğunu ve neden orada olduğunu açıklar; diğer bir deyişle, mekanizma X'in Y'yi soyut etkileme özelliği ya da etkileme sürecidir. Hatta, bazı durumlarda, örneğin tarihsel sosyolojik olgularda mekanizmalar zaman ve mekânda gözlenebilir değildir. Mahoney (2016: 494), bu yaklaşım reddetmese de, süreç takibinde sıklıkla kullanılan bir yaklaşım olmadığı öne sürmektedir. 


\section{Süreç Takibiyle Nedensel ve Zamansal Analiz Teknikleri}

Süreç takibi nedensel ve zamansal analizi mümkün kılar. Küme kuramıyla nedensel çıkarım üç yolla yapılır: gerek-şart, katkı sunan şart ve INUS şart. Süreç takibiyle zamansal analiz genellikle, bir kırılma noktası (critical juncture) belirleyerek izlek bağımlılığı analizidir. Bu bölüm ilk olarak, gerek-şartın belirlenmesinde karşı-olgusal düşünme tekniği ve katkı sunan şartla ilgili çıkarımların nasıl yapıldığını Soğuk Savaş'ın bitişine dair vaka analiziyle inceler. INUS şartı Irak Savaşı'na demokratik katılım üzerine çıkarımlarla örneklendirir. İkinci olarak, izlek bağımlılığını Orta Amerika'da liberalizmin mirası olan siyasi rejimler üzerine vaka analiziyle açıklar. Son olarak, bu yöntemin sunduğu çıkarımsal faydaları değerlendirir.

Nitel yöntem matematiksel mantıkla çıkarım yaparak, yani gerek ve yeter şartlar üzerinden vakalara yaklaşır. Tarihsel araştırmada tek ya da az sayıda vakada ardışıklığın gerek-şart üzerinden analizini yaparken karşı-olgusal (counterfactual) çıkarım şu düstura dayanır: gerek-şartın yokluğu sonucun da yokluğu demektir (Mahoney, 2015: 203). "Soğuk Savaş neden sona ermiştir?” sorusunu ele alalım. English (2007), Soğuk Savaş'ın bitmesini Sovyetler Birliği'nin ekonomik iflasına bağlayan realist yaklaşımı eleştirir. Bu hipotezin liderlerin etkisini göz ardı ettiğini, gerekli ve yeterli şartları birbirine karıştırdığını iddia eder. Soğuk Savaş’ın ani ve barışçıl bitişi için sine qua non, yani olmazsa olmaz şart Perestroyka fikridir; 1970'lerden beri, ülkenin durumu ve uluslararası siyasetteki rolü üzerine yenilikçi görüşleri tartışan, akademide ve kamu politikasında Batılılaşma yanlısı liberal entelektüellerin etkisi olmazsa olmaz şarttır. Sovyetler Birliği'nde öncel fikirsel ve ekonomik şartlar Sovyet ‘yeni düşüncesinin' tek tek gerekli ve birlikte yeterli nedenleridir. Sovyet 'yeni düşüncesi’ Soğuk Savaş’ı bitiren gerek-şarttır. Karşı-olgusal çıkarımla, Sovyet 'yeni düşüncesi' olmasaydı veya Mihail Gorbaçov farklı bir yol seçseydi, Soğuk Savaş'in statükocu veya şahin siyaset alternatifleriyle devam edebileceği öne sürülmüştür (English, 2007: 256).

Küme kuramıyla nedensel çıkarım yapmada ikinci yol 'katkı sunan şarttır', yani gerek-şart olmayan, fakat sonucun ortaya çıkmasına yardım eden, onun ortaya çıkma ihtimalini yükselten şartlardır. Gerek-şartın yokluğu sonucu imkânsız kılarken, katkı sunan bir şartın yokluğu sonucu imkansızlaştırmayacaktır. Katkı sunan bir şart başka etkenlerle birleşerek sonucu daha mümkün hale getirdiğinden sonuç daha çok ihtimal dahiline girecektir. Bu tür bir süreç takibini doğru uygulayabilmek için geniş bir evrende nedensellik örüntülerini ve incelenen vakada nedenlerin sonucun oluşmasına ne ölçüde yardımcı olduğunu bilmek gerekir. Yukarıdaki örnekten devam edecek 
olursak, realist yaklaşımlar liberal düşüncenin etkilerini Soğuk Savaş’ın bitişi için katkı sunan şart olarak ele almaktadır.

Küme kuramıyla nedensel çıkarımda üçüncü yol INUS şarttır. INUS şart, tek başına sonuç için ne gerek ne de yeter-şarttır, fakat başka etkenlerle birleşerek sonucu ortaya çıkarır. Nedenler paketinin kendisi sonuç için yeter-şarttır. Nedenlerin birleşimi ile eş-sonuçluluğun her ikisi de mevcutsa INUS şart da mevcuttur. INUS şartı teyit etmek için aynı sonuca götüren birden fazla nedensel izlek (causal pathways) olması ve bunlardan en az birinin nedensel birleşim olması gerekir (Mahoney, 2015: 203-204). Mello (2014: 177-178), 2003'te 30 demokrasinin Irak'taki savaşa katılma(ma) kararına götüren nedensel izlekleri incelemiştir. Parlamentoda silahlı çatışmaya demokratik katılımın reddi için yeterli iki nedensel birleşim öne sürülmüştür: Parlamentonun veto hakkı, savaşa katılımın anayasayla kısıtlanması ve kamuoyu muhalefeti savaşa katılmama kararı için ilk nedensel pakettir. Sol hükümet, parlamentonun veto hakkının olmaması ve kamuoyu muhalefeti ise ikinci nedensel pakettir. Anayasal kısıtların olduğu ülkelerin hiçbiri savaşa katılmamıştır. Anayasal kısıtlar katılmama kararı için yeter-şart olmuştur, anayasal kısıtların yokluğu katılma kararı için gerek-şart olmuştur.

Zamansal analizde ardışıklık analizi ardışık olayları takip etmektir. ${ }^{8}$ Ardışıklık analizi süreç takibini zorunlu kılar, çünkü amaç bir sonuca götüren olay ve etkenlerin sırasıyla neler olduğunu açıklamaktır. Ardışıklık analizi genelde belli olay ya da aktörlerin verdiği kararların, yaptığı seçimlerin araştırılan analiz birimiyle ilgili bir kırılma noktası oluşturduğu durumlarda uygulanır. Bu süreç eğer izlek bağımlılığını açığa çıkarıyorsa, yani kırılma noktasından sonra geri bildirim mekanizmasıyla (feedback mechanism) $(\mathrm{X} \rightarrow \mathrm{Y} \rightarrow \mathrm{Z} \rightarrow \mathrm{X})$ neden ve sonuç yeniden üretiliyorsa, mekanizmaya dair bilgi daha önemli hale gelir. İzlek bağımlılığının tarihsel analizi, yapan ile yapı arasındaki ilişki temelinde gelişen bulmacaları çözmeyi, toplumsal ve kurumsal yapılar ile yapanın kararları ve eylemlerinin buluştuğu bulmacalar1 çözmeyi amaçlar (Capoccia ve Ziblatt, 2010). İzlek bağımlılığının analizi, zamansal olarak sonuca götüren nedensel izleğin açığa çıkarılmasını sağlar; ardışıklığın analizinde bir kırılma noktası (critical juncture), dolayısıyla geri bildirimsel süreçlerin olup olmadığını tespit eder (Mahoney, 2015: 204-206).

8 Pierson (2011: 81) Zamanda Siyaset (Politics in Time) başlıklı kitabında neden ve sonucun zamansallığını açıklamak için metaforlara (tornado, göktaşı, deprem ve küresel ısınma) başvurur. Hem açıklayan etkenler hem de açıklanan sonuç zamansallığa tabidir, bu zamansallığa bağlı olarak nedenlerin ve sonucun kısa veya uzun bir zamansallığa tabi olduğuna bağlı olarak nedensellik farklılaşır. Tornado, neden ve sonucun birbirine yakın ve kısa sürede meydana geldiği; göktaşı, nedenin kısa zamanda sonucun uzun sürede meydana geldiği; deprem, nedenin uzun sürede sonucun ise kısa sürede meydana geldiği süreçlerdir. 
Vaka-içi analiz sapkın (outlier, deviant) vakalar gibi kuramsal öneme haiz vaka seçimiyle veya vakalar-arası analizle güçlendirilebilir. "Liberalizmin Mirasları” (Mahoney, 2001) dört ülkede vaka-içi gözlemleri vakalar-arası karşılaştırmayla perçinleyen bir çalışmadır. Çalışma, 19. yüzyılda erken kapitalizmde, Orta Amerika'da liberal elitlerin kararlarının bu ülkeleri belli nedensel izleklere bağımlı hale getirdiğini iddia eder. 19. yüzyılda Orta Amerika'da diktatörlerin kilisenin ve geleneksel aktörlerin rolünü zayıflatmak ve devletin gücünü genişletmek amacıyla reformcu ya da radikal liberalleşme politika kararı kırılma noktası olmuştur. Bu kararlar devlet kurumlarının oluşmasına, özellikle ordunun rolüne kritik etkide bulunmuştur. Kırılma noktaları, ülkeleri geri bildirim mekanizmasıyla kendini yeniden üreten süreçlere götürmüş, izlek bağımlı 20. yüzyıl ortasında bölgede belli siyasi rejimlerin oluşmasına neden olmuştur. Guatemala ve El Salvador'da radikal liberal reformların mirası askeri-otoriter rejimler, Kosta Rika'da reformist liberal reformların mirası liberal demokrasi, Honduras ve Nikaragua'da liberalleşme sürecinin başarısızlığa uğraması geleneksel diktatörlükler olmuştur. Liberal elitlerin ve yakın müttefiklerinin kararları, yapı ile yapanı, ekonomik sistem ve siyasi elitleri bir araya getirerek, aktöre yapıyı değiştirmek için bir fırsat penceresi sunmuştur. İzlek bağımlılığı açıklamaları şu analitik ardışıklığı tarif eder: öncel koşullar (aktörlerin önündeki mevcut seçeneklere yön veren tarihsel etkenler) $\rightarrow$ kırılma noktası (aktörlerin farklı liberalleşme alternatifleri arasından belli bir seçim yapması) $\rightarrow$ yapısal direnç (kurumsal veya yapısal örüntünün (pattern) ortaya çıkması ve sonra kendini yeniden üretilmesi) $\rightarrow$ tepkisel ardışıklık (kurumsal örüntüye tepki veya karşı-tepki) $\rightarrow$ sonuç (tepki ve karşı-tepkilerden oluşan çatışmanın sonuçlanması).

Süreç takibi yönteminin çıkarımsal kazanımları beş hususta özetlenebilir. İlk olarak, giriş bölümünde aktarıldığı üzere sahte nedensellik ilişkilerini göz önünde bulundurur, hipotezleri test etmeye yarar. İkinci olarak, süreç takibi sayesinde nedenselliğin yönünü iyi tayin edilmemiş olmasından kaynaklı çıkarım hataları tespit edilebilir. Üçüncü olarak, mekanizmaların nedensel ardışıklık çerçevesinde incelenmesiyle, göz ardı edilmiş bir değişkenden kaynaklanan önyargı (omitted variable bias) önlenebilir. Bir sapkın vaka süreç takibi yöntemiyle incelenirken göz ardı edilen değişken teşhis edilip o vakanın aslında tipik vaka ya da kritik vaka (crucial case) olduğu ortaya çıkabilir. Dördüncü olarak, süreç takibi vaka içinde nedenselliğe zaman boyutunu eklediğinden mekanizmada sonucun nedeni yeniden üretmesi, yani döngüsel nedensellik ilişkilerini tespit edebilir. Son olarak, açıklayıcı olduğu varsayılan nedenin aslında bağlama dahil olan ama hesaba katılmayan bir nedenin 
etkisiyle oluşmuş olabileceğine işaret eden içsellik (endogeneity) sorunu süreç takibiyle çözülebilir (Bennett ve Elman, 2006).

Süreç takibiyle geliştirilen kuramların genelleme gücü kapsam koşullarına (scope conditions) bağlıdır. Kapsam koşulları kuramsal temellendirmeye tabidir ve vaka seçiminde rol oynar. Küme kuramına başvurursak, 'kapsam koşulları' üst kümesinin alt-kümeleri açılamak istediğimiz olguya karşılık gelen 'olumlu vakalar' kümesi ile 'olumsuz vakalar' kümesidir. İki kümenin kesişimi gri alanda yer alan vakaların kümesidir. Üst ve alt kümeler arasında kalan boşlukta ise ilgili olmayan vakalar yer alır (Goertz, 2006: 160). Zaman ve mekâna bağlı kapsam koşullarını bilmek genelleme yapma şartlarını bilmek anlamına gelir. Araştırmacılar hangi önermelerin ilgilendikleri birim ve vakaya dair olduğunu ve hangilerinin daha geniş birim kümesine ait olduğunu netleştirmelidir. Nitel kültürde mantık ve küme kuramına dayalı belirlenimci anlayış, zamansal ve mekânsal kapsam koşulları, yani bağlamı belirlenmiş bir olguya dair süreç takibinin ortaya çıkardığı nedensel mekanizmaların aynı bağlamda aynı sonuca ulaşacağı varsayımına dayanır (Bennett ve Checkel, 2015: 13-14).?

\section{Süreç Takibiyle Kuram Testi ve Kuram Geliştirme}

Bu bölüm, Bayesci mantıkla kuram testinde kullanılan teknikleri ve kuram geliştirme stratejilerini karşılaştırmalı siyaset literatüründen örneklerle uygulamalı olarak tanıtır. ${ }^{10}$ Süreç takibi testleri bilimsellik ile yanlışlanabilirlik arasında kurulan Popperci bağın (Popper, 1969) nitel yöntemde sistemleşmesidir. Thomas Bayes (Price, 1763), ${ }^{11} 18$. yüzyıl ortasında olasılık kuramlarından kanıta dayalı olasılık yaklaşımını geliştirmiştir. Bayesci mantığı gündelik hayatta, önceden deneyimlemiş ve belli bir olabilirlik düzeyine kâni olduğumuz hipotezleri yeni bir kanıt ortaya çıktığında tekrar değerlendirdiğimizde kullanırız. Yeni kanıt çerçevesinde belli bir hipotezin ne kadar doğru olabileceğini, önceki deneyime bağlı olabilirlik düzeyini hesaba katarak değerlendirip yeni bir ikna düzeyi belirleriz. Bu bölümde, süreç takibinde sıklıkla kullanılan halka testi ve dumanı tüten silah testi Türkiye'nin Irak Savaşı'na katılmama kararı, Soğuk Savaş’ın sona ermesinde Sovyet 'yeni düşüncesinin' etkisi,

9 Olasılıkkuramında, nicel nedensellik anlayışında stokastik anlayış tanım itibariyle belli mekanizmaların işleyişinde değişkenlerin değerlerinin değişmesi ihtimalini, dolayısıyla mekanizmanın farklı işleyerek farklı bir sonuca götürme ihtimalini barındırmaktadır. Bu tür mekanizmalar üretici mekanizmadır (generative mechanism). Süreç takibi olasılıkçı anlayışa göre uygulandığında zamansal ve mekânsal kapsam koşulları (scope conditions) özellikle dikkate alınmalıdır (Trampusch ve Palier, 2016: 439).

10 Süreç takibinin formal Bayesci mantıkla uygulanışı ile ilgili bkz. Bennett, 2015.

11 İngiliz matematikçi ve ilahiyatçı Bayes, yaşarken tevâzusunun yayınlatmaya el vermediği çalışmalarının Richard Price'a verilmesini vasiyet etmiştir. Ölümünden iki yıl sonra Price, Bayes teoremini Kraliyet Akademisi'ne sunmuştur ve teorem yayınlanmıştır. 
Türkiye'de kent politikaları üzerine vaka analizlerindeki hipotezler test edilir. Kuram geliştirme stratejileri Balkanlar'da Türk azınlıkların hakları, Doğu Asya'da kalkınmacı devletler, Orta Amerika'da liberalizmin mirasları üzerine vaka analizleriyle örneklendirilir.

İyi bir süreç takibi uygulaması için araştırmacının vaka-içi analizde çıkarım yapılan birim hakkında tarihsel arka planı bilmesi, ilgili kuramlara ve genellemelere vakıf olması, çıkarım yapmak için gerekli yöntemsel tekniklere vakıf olması, kısaca kuramsal hipotezler ile vaka bilgisini birleştirerek analiz yapmada yetkin olması gerekir. Uygulamanın kalitesini yükseltecek kurallar aslında her araştırmada uyulması gerekli kurallardır: süreç takibi yaparken mevcut tüm alternatif hipotezler analize dahil edilmelidir; alternatif, rakip açıklamalara önyargısız yaklaşılmalıdır, eşit değer verilmelidir; kanıttan ya da araştırmacı olarak kişisel özelliklerden kaynaklanabilecek önyargıllar göz önünde bulundurulmalıdır (Mahoney, 2015: 202).

Tümdengelimsel süreç takibinde, yani kuram testinde, belli bir vakada olayların sonuca nasıl götürdüğünü araştırırken kuram bize rehberlik eder. Kuram testi denildiğinde genelde akla kuramı başka bir vakada test etmek gelir. Süreç takibi testlerinin amacı, hipotezlerin başka vakalarda testinden ziyade, kuram geliştirme sırasında göz ardı edilmiş alternatif açıklamalar olup olmadığını kanıtlar aracılığıyla sınamaktır (Mahoney, 2012: 587). Bayesci mantık tek ya da az-S vaka üzerine açıllamaları değerlendirmeye, vaka-içi kanıtlardan yola çıkarak kuramlar hakkında çıkarımda bulunmaya yarar. Süreç takibi, nedenin sonuca nasıl götürdüğünü açıllamak için hipotezleri kanıtlarla test etmeyi, nedenler ve sonuç arasında tekrar tekrar gidip gelmeyi gerektiren bir süreçtir. Süreç takibinde vaka(lar) kendi içinde ardışık olayların tespit edilmesi ile parçalanır. Amaç, pek çok kanıt öne sürmeyi, kuramların hipotezlerini karşılaştırmayı ve en iyi açıklamayı bulmaktır. Aslında bu mantığa dedektif filmlerinden, jürili mahkeme sahnelerinden ya da bir doktorun hastalığı teşhis etmek için yaptığı alternatif testlerden aşinayız (Mahoney, 2016). ${ }^{12}$

Van Evera (1997: 31-32), testlerin bir tipolojisini yaparak küme kuramina göre sınıflandırmıştır. Halka testini geçmek hipotezin geçerliğini kanıtlamak için gerekli ama yeterli değildir; dumanı tüten silah testini geçmek hipotezin geçerliğini kanıtlamak için yeterli ama gerekli değildir; çifte belirleyici testi (doubly-decisive test) geçmek hipotezi kanıtlamak için gerekli ve yeterlidir; ilk haberci veya ilk belirti testi (straw-in-the-wind) ne gerekli ne yeterlidir, zayıf veya ikinci derecede kanıttır. Bu çalışmada, vaka-içi gözlemlere en çok

12 Collier (Doyle, 2012; aktaran Collier, 2011) süreç takibine dair testleri örneklerken Sherlock Holmes'un “Gümüş Şimşek” başlıklı hikayesinden faydalanmıştır. 
uygulanan 'halka testi' (hoop test) ve 'dumanı tüten silah testi' (smoking-gun test) üzerinde durulacaktır. Halka testi hipotezlerin ikna edici bir şekilde elenmesi, dumanı tüten silah testi hipotezlerin ikna edici bir şekilde teyit edilmesi işlevini görür. Polisiye filmlerden aşina olduğumuz bir soru şudur: “Şüpheli cinayetin işlendiği zaman olay yerinde miydi?” Şüphelinin cinayet işlenirken olay yerinde olmadığının kanıtı kesin bir şekilde o kişinin katil olduğu hipotezini çürütür. Halka testini geçememek hipotezin geçerliliği için güçlü bir şüphe uyandırır, testi geçmek (olay yerinde olmak) hipotezi teyit etmez. Şüphelinin, maktulün önünde elinde dumanı tüten bir silahla çekilmiş fotoğrafı şüphe hipotezinin doğru olduğuna dair güçlü destek verir, ama silahın yokluğu hipotezi çürütmez. Çifte belirleyici testi geçen kanıt, örneğin şüphelinin cinayeti işleme anının kamera görüntüleri hipotez hakkında çok güçlü bir kanıttır.

Halka testinde hipotezi geçmek bazı durumlarda anlamlı olabilir. Hipotezi kanıtlamak için öne sürülmesi gereken gözlem veya kanıt analizi yapılan vaka için ne kadar nadir, hatta istisnai ise testi geçmek o kadar zor olacaktır. Zor halka testinin hipotezin doğruluğu hakkında ikna edici gücü yüksektir. Fakat söz konusu gözlemler her zaman mevcutsa, testi geçmek kolay olacağından testin değeri azalır. Dumanı tüten silah testini geçmemek de bazı durumlarda anlamlı olabilir. Kolay bir dumanı tüten silah testini geçememek hipotezi zayıflatabilir (Mahoney, 2012: 579-583; Mahoney ve Vanderpoel, 2015: 206-211).

Süreç takibiyle hipotez testi için sorulan soru şudur: “Z vakasında Y’nin nedeni X midir?” Bir dedektif davayı çözerken eldeki vaka ve vakanın tarihçesi hakkında bilgiye, ilgili başka vakalar hakkında bilgiye, hatalı açıklamaları çürüten ve geçerli açıklamaları destekleyen kanıtlara ihtiyaç duyar. X'in Y'ye yol açtığı hipotezini öne sürüyorsak, aradaki olay ve etkenler hakkında ikna edici bir olaylar zinciri kurabilmemiz gerekir. Ayrıca, hipotezin teyit edilmesi için kanıt sunmak gerekir. Ampirik veri açısından zengin vaka analizlerine, nedenden sonuca götüren süreci tasvir eden betimleyici açıklamalara gereksinim duyarız. Süreç takibi testlerinde betimleyici çıkarımlar nedensel çıkarımlara, gerekli ve yeterli şartlar çerçevesinde çıkarımlara, kanıt olurlar. Testler sırasıyla gerek-yeter şartı, gerek-şartı veya yeter-şartı karşılayamadığ1 oranda 'ilk belirti' testi haline gelerek açıllama gücünü yitirirler (Mahoney, 2012: 572-575).

Halka testlerini nasıl yaparız? Öncül halka testinde X ve Y'nin gerçekten meydana gelip gelmediğini, X ile Y arasında fiziksel ya da kuramsal bir ilinti imkânı olup olmadığını sorarız. 1 Mart 2003'te TBMM Irak Savaşı ile ilgili tezkereyi gerçekten reddetti mi? Dış politikada karar alma kuramları 
çerçevesinde, Türkiye'de hangi birimler ve aktörler bu karar mekanizmasında etkiliydi? Bunlar karar öncesinde hipotezde betimlendiği durumda mıydı? Hipotez bu öncül testlerden geçmezse çürütülmüş olur. Geçerse, mekanizmanın ya da olaylar zincirinin testine geçilebilir. Ayrıca, hipotez sonuca götüren herhangi bir olaylar zinciri tanımlamıyorsa da halka testi aşamasına geçilemez. Halka testi aşamasına geçilirse, hipotezleri test etmek için alternatif açıklamalar kanıtlar ışığında değerlendirilir (Mahoney, 2015: 208-210). Taydaş ve Özdamar, 2003'te meclisten çıkan ret kararının arkasında hükümetin bölünmüşlüğü, meclisin ideolojik tutumu ve başbakanın güvensizliğine dair olaylar zinciri tespit etmiştir. ${ }^{13}$ Araştırmacılar süreç takibini titizlikle uygulamış olduklarından, hipotezleri destekleyen kanıtların hangi test tekniğinde kullanılabileceğini metinden çıkarabiliriz. Başbakan Abdullah Gül'ün, çıkacak kararın sorumluluğunu ordunun da üstlenmesi beklentisiyle meclis oylamasını Milli Güvenlik Kurulu (MGK) toplantısından sonraki bir tarihe alması halka testinde kullanılabilecek bir kanıttır. Sürpriz bir şekilde, siyasette o güne kadar nadiren sessiz kalan MGK, orduyu doğrudan ilgilendiren bir konuda tavsiyede bulunmamıştır (Taydaş ve Özdamar, 2013: 229). MGK'nın bir tavsiye kararı olsaydı, liderin davranışının nedensel birleşimdeki rolünü o kanıt ışığında tekrar değerlendirmek gerekirdi.

Dumanı tüten silah kanıtı, hipotezi hedefleyen spesifik, özgün, ama kesin olmayan kanıtlardır. Karşı-olgusal bir çıkarım içeren şu ifadeler, başbakanın kararsızlığı etkeninin, diğer etkenlere göre ret kararında ağırlığı daha fazla olan bir gerek-şart olarak değerlendirildiğini gösterir: “Recep Tayyip Erdoğan karar sürecinde başbakan olsaydı, partili milletvekillerini 'evet' oyu için daha fazla etkilerdi” (Taydaş ve Özdamar, 2013: 238). 7 Ekim 2003’te, 6 aydır başbakan olan Erdoğan'ın ağırlığını koyarak, kamuoyunda Irak’a müdahale karşıtlığının artmasına rağmen hem parti içi anlaşmazlığı hem de kamuoyu muhalefetini aşarak Irak’a asker gönderme kararını etkilemiş olması (2013: 238) dumanı tüten silah testine kanıttır. Kanıt hipoteze güçlü destek vermiştir, ama böyle bir kanıt olmasaydı hipotez çürütülmüş olmazdı.

English (2007: 238-254), realist hipotezin ekonomik çöküş Soğuk Savaş'ın bitişi için gerek-şart olduğu hipotezine karşı çıkar. Bu hipotez, Kremlin'in ekonomik çöküş nedeniyle baskı altında değişim kararı verdiği tezine dayanır. Başka bir deyişle, Kremlin üstündeki baskı ekonomik çöküş (gerek-şart) ve Soğuk Savaş’ın bitişi (sonuç) arasında yeter-şart işlevini görmektedir. Yazar

13 Taydaş ve Özdamar (2013:236) Türkiye'yi parlamenter demokrasi kümesine koymuş olmakla birlikte, Mello (2014: 155) vaka seçiminde demokrasi değerleri belli bir eşiğin üstündeki vakaları kapsadığından Türkiye analize dahil edilmemiştir. Bu yüzden, nedenler birleşiminde eş-sonuçluluğun, dolayısıyla INUS şartların olduğunu iddia etmek mümkün olmadığından burada tekil birleşim olarak ele alınmıştır. 
tarihsel dönemi incelemek için, Politbüro'nun üst düzey üyeleri ve üst düzey bürokratların biyografilerini, mülakatları ve arşivleri taramıştır. 1980'lerin sonlarına kadar Sovyet sisteminde radikal bir kemer sıkma politikasına alternatifler olabileceğinin düşünüldüğüne, Politbüro üyelerinin çoğunluğunun yolsuzluğa bulaşmış olduğuna, durumu idare etmeye çalıştıklarına dair kanıtlar realist tezin halka testi olarak görülebilir. Politbüro'da şahinlerin karşı çımasına rağmen, 1980'lerin sonlarında reformist liderliği üstlenen azınlık ile Batılılaşma yanlısı liberal düşünürler değişime yön vermiştir. ${ }^{14}$ Realist hipotez şu argümanla eleştirilmektedir: “1980’lerin ortasında, ekonomik darboğazda olan çoğulcu devletlerdeki liderlerin maruz kaldığı gibi, Politbüro baskıya maruz kalmış olsaydı, bu tür bir darboğaz ve arkasından gelen politika değişimi arasındaki korelasyon esas kanıt olabilirdi. Ancak, Kremlin, en azından 1980'lerin sonuna kadar böyle bir baskı altında kalmadı, o zaman Gorbaçov zaten ‘yeni düşünce’ cesur girişimini yapmıştı.”(English, 2007: 238)

Türkiye ve Kolombiya'da kent politikalarının süreç takibi yöntemiyle vaka-içi analizi, kent idaresini manipüle etmenin yerel siyasetçilere oy artırma ve destekçileri ödüllendirme fırsatı sunduğunu göstermiştir (Bozçağa ve Holland, 2018). İki mekanizma (eş-sonuçluluk) tespit edilmiştir: Kolombiya'da müsamaha (forbearance), Türkiye'de maksadı sulandırma (dilution). Türkiye'de vaka-içi analiz partiler-arası rekabetin az olduğu, yerel siyasetçilerin bürokrasilerinin kontrolünü sağladıkları ilçelerde ve merkezi devlet kaynaklarına erişimi az olan muhalefet parti belediyelerinde imar izninin yerel seçim döngüsüne bağlı olduğunu tespit etmiştir. Türkiye vakasında (2002-2016) dumanı tüten silah kanıtı nicel bir analizle sunulmuştur. İstatistiksel karşı-olgusal analizle pek el değiştirmeyen seçim bölgeleri ile kararsız seçmenlerin olduğu seçim bölgeleri seçim yılı ve seçim öncesi yılı (kontrol grubu) bazında test edilmiştir. Sezona bağlı inşaat artışı gibi alternatif açıklamalar elendiğinde, imar izinlerinin seçimden bir ay önceki dönemde, seçim olmayan bir sene öncesine göre ikiye katlandığı gözlenmiştir. İmar izinlerinin, belediye yetkililerinin takdir yetkisi kullanarak, düzenlemelerde suç tanımını manipüle ederek maksadı sulandırma yoluyla imar onayı verdiği öne sürülmüştür (Bozçağa ve Holland, 2018: 314-317).

Kuram geliştirmek kuram testinden daha zordur. Belli bir vakada neden ve sonuç arasında bir bağ olup olmadığını güçlü bir kanıtla test ederek nedenselliği ispatlayabiliriz. Fakat nedenin sonucu nasıl etkilediğini etraflıca açıklamak için ne ölçüde mikro ölçeğe gidileceği veya tarihsel anlamda nedensellik ilişkisinde ne kadar geriye gidileceği sorusunu yanıtlamak daha

14 Araştırmacılar kuram testine örnek verilen eserlerde pek çok kanıt öne sürmüşlerdir. Tüm kanıtların aktarılması bu makalenin amacını ve sınırlarını aşar. 
zordur. Kuram geliştirmekte amaç, ya yeni ve özgün hipotezler geliştirmek ya da mevcut kuramsal literatürde yer alan hipotezleri düzeltmek veya değiştirmek olabilir. Üç strateji kullanılır. İlk stratejide amacı, tümevarımsal süreç takibiyle, hakkında literatürde kuram bulunmayan olay ve ardışıklıkları, dolayısıyla potansiyel nedensel süreçleri keşfetmektir. İkinci stratejide amaç, mevcut bir kurama dayanarak kuram geliştirmektir. Mevcut hipotezdeki nedenler ya da nedensel birleşim düzeltilir veya değiştirilir. Üçüncü strateji karşı-olgusal analizdir. Karşı-olgusal analizde dikkat edilmesi gereken nokta, sonuca götüren gerek-şartın yokluğunun gerçek hayatta düşünülebilmesidir. Gerek-şartın yokluğunda tarihin önemli ölçüde değişmeyeceği düşünülebilmelidir: o atipik, küçük, tesadüfi, talih işi olay olmasaydı, bir film gibi o olayı yaşandığı an durdurup geriye sarabilseydik (ve o olaydan önceki bazı şartlar biraz farklı olsaydı), dünyanın muhtemel gidişatındaki alternatif senaryoların birçoğunda o olayın yaşanması mümkün olmazdı, dolayısıyla sonuç da ortaya çıkmazdı. Hem atipik bir olay olmak hem de önemli olayların nedeni olmak paradoks gibi gözükse de, küçük bir olayın her zaman bağlam koşullar1 1şığında nedensel ağırlığı olduğu, başka bağlamlarda olmayabileceği göz önünde bulundurulmalıdır. Kuram testi eğer karşı-olgusal çıkarımla yapılırsa, bu nokta çok daha fazla önem taşır (Mahoney, 2015: 212-217).

Tümevarımsal süreç takibi uygulayan Aktürk ve Lika (2020) mevcut hipotezlerin açıklayamadığı bir bulmacaya odaklanmıştır. Birbirine pek çok açıdan benzeyen Bulgaristan, Yunanistan ve Kuzey Makedonya'daki etnik azınlık rejimleri Türk azınlığın kayda değer siyasi temsiline rağmen önemli ölçüde farklılaşmaktadır. Sadece Kuzey Makedonya'da Türk azınlığın siyasi temsilinin ve Türkçe'nin resmi dil statüsünün teminat altına alınmış olması bir bulmacaya benzetilmiştir. Öncelikle muhtemel hipotezler taranmıştır, hiçbiri halka testini geçememiştir. Siyasi temsilin etkisine yönelik hipotez, Türklerin mecliste güçlü bir şekilde temsil edildiği, hatta koalisyon hükümetlerinde yer aldığı ülke Bulgaristan iken siyasi kabulün Kuzey Makedonya'da en yüksek oranda olmasını açıklayamamıştır. Avrupa Birliği üyeliği, demokrasinin düzeyi, Türkiye'nin diplomatik baskısı (Lozan Antlaşması, uluslararası lobi faaliyetleri, vb.) ve Türk azınlığın siyasi seferberliği de durumu açıklayamamıştır; açıklasalardı, en yüksek siyasi kabulün Yunanistan veya Bulgaristan'da olması gerekirdi. Dış müdahalenin etkisine dair hipotez de oldukça güçlü bir hipotez olabilecekken halka testini geçememiştir, çünkü Ohri Çerçeve Antlaşması Arnavutların azınlık statüsünü yükseltirken, diğer etnik azınlıkların statüsünü düşürmüştür (Aktürk ve Lika, 2020: 6-10).

Aktürk ve Lika, bu bulmacada Türk azınlığı ve Türkçe dilinin anayasal kabulünün nedenlerini bulmak için her vakada nedensel öneme haiz tarihsel 
dönemleri mercek altına tutmuştur. Vaka-içi analiz Türk azınlığı temsil eden siyasi aktörler ve en büyük siyasi partiler arasındaki ilişkiye odaklanmıştır. Bu etkileşimin her ülkede nasıl ilerlediği, azınlık ve dil kabulünü nasıl etkilediği siyasi liderlerle mülakatlar gibi birincil kaynaklar da kullanılarak tartışılmıştır. Kuzey Makedonya'da ulusal kimlik konusunda büyük siyasi partiler arasında yaşanan siyasi kutuplaşmanın Türk azınlığın resmi kabulüne neden olduğu ileri sürülmüştür. Bu hipotez 'milliyet çatlağı' veya 'milliyet fay hattı'15 (nationhood cleavage) olarak kavramsallaştırılmıştır. Araştırmacıların açıkça ifade ettiği gibi, milliyet çatlağı/fay hattı etnik-dilsel anayasal kabul için gerek-şarttır; anayasal statü talep etme amacıyla siyasallaşan azınlığa mensup milletvekillerinin varlığı ise yeter-şarttır (2020: 5-6).

Doner, Ritchie ve Slater (2005: 329-332), kalkınmacı devletleri ortaya çıkaran nedensel mekanizmayı tespit ederek kuram geliştirmişlerdir. Araştırmacılar mevcut literatürden, elitleri kısıtlayan unsurların ve belli koalisyon baskılarının kurumsal gelişime etkisine dair çalışmalardan faydalanmışlardır. Açıklayıcı etkenleri zamansal ardışıklık takibiyle literatürden farklı bir şekilde birleştirerek şu hipotezi oluşturmuşlardır: 'sistemsel savunmasızlık' Güney Kore, Tayvan ve Singapur vakalarında kalkınmacı devlete neden olan gerek-yeter şarttır. Sistemsel savunmasızlık üç gerek-şartın birleşimine bağlanmıştır: geniş koalisyon taahhüdü, ciddi güvenlik tehdidi ve kıt kaynaklar. Siyasi elitler iktidarlarını sürdürebilmek için kurdukları koalisyonları -kontrolü daha kolay ve daha az masraflı olduğundan- mümkün olduğunca dar tutmaya çalışırlar. II. Dünya Savaşı'ndan sonra Güney Kore, Tayvan ve Singapur'da toplumsal çatışma ve kitlesel hareket tehdidi altında dar koalisyonlar iktidarı sürdürmeye yetmemiş, elitler geniş koalisyon taahhüdünde bulunmak zorunda kalmıştır. Geniş koalisyonlarda elitler halkın desteğini ya da kabulünü sürdürmek için kamu sektörüne destek ödemeleri -koalisyon ortaklarına mal ve hizmetler- aktarır. Bu ülkelerde ciddi güvenlik tehdidi mevcut olduğundan destek ödemelerinin savunma harcamalarını engellememesi gerekmiştir. Ciddi güvenlik tehdidine jeopolitik ve maddi kısıtların eklenmesi, elitleri hayatta kalma mücadelesine sokmuştur. Destek ödemeleri yapmanın ekonomik kalkınma olmadan mümkün olmaması, elitlerin düşük ücretli emeğe dayalı ihracatı terk etmelerine, kıt kaynakları yüksek eğitim ve beceri

15 'Milliyet çatlağı/fay hattı' milli kimliğin ve tarihsel kökenlerinin tanımlanmasında, millete üyelik anlamında kimlerin millete ait olduğunun sınırlandırılmasında anlaşmazlığı ifade etmektedir (Aktürk ve Lika, 2020: 10-11). Burada fay hattı genel anlamda farklı etnisitelerin varlığı anlamına gelmez. Milliyet konusunda temelde yarılmaya, deprem metaforunun çağrıştırdığı gibi, kimliksel tehdit algısına yol açan bir kutuplaşmaya karşılık gelmektedir. 
isteyen, yüksek artı-değeri olan ürünlerin ihracatına yönlendirmelerine neden olmuştur. Böylece, kalkınmacı kurumlar ortaya çıkarmıştır.

Mahoney, Orta Amerika'daki siyasi rejimlerin analizinde, literatürde olmayan yeni nedensel etkenler keşfederek ardışıklık analizi yapmıştır. Kırılma noktalarının tespiti, yani vakaları geri dönüşü zor bir izleğe bağımlı yapan etkenler hakkında güçlü karşı-olgusal hipotezleri barındırır. ${ }^{16}$ Yapı ile yapanın buluştuğu kırılma noktasında, liberal elitler farklı kararlar vermiş olsaydı, Guatemala, El Salvador, Kosta Rika, Honduras ve Nikaragua'da siyasal rejimlere götüren izlek değişir miydi? İzlek bağımlılığı açıklamaları bu soruya olumlu yanıt verir. Kırsal sınıfsal değişimlerin devlet yapısında değişikliğe yol açtığı varsayımı aşırı belirlenmiştir (overdetermined). Her ne kadar kırsal elitlerin çıkarlarını da gözetmeleri gerekse de, diktatörler kendi çıkarlarına ters düştüğünde, hâkim sınıfların çıkarlarına ters düşen kararlar vermişlerdir. Guatemala'da radikal liberaller toprak reformuyla geleneksel arazi sahipliğini zayıflatarak kapitalist ticari tarımı desteklerken, köylü ve küçük ölçekli üreticiler güçsüzleşmiştir. Bu reformlar büyük kahve arazisi üreticilerinin güçlenmesine yol açmıştır. Kosta Rika'da, reformcu liberaller kapitalist ticari tarımı desteklerken küçük tarım işletmelerini korumuşlardır. Kırsal isyan gibi ciddi güvenlik tehdidi olmadığından ve büyük, ticarileşmiş tarım sektörünün yokluğundan 19. yüzyılda yapılan reformlar küçük ölçekli üreticilerin ortaya çıkmasını desteklemiş, kırsal kutuplaşmayı ve ordunun rolünü kisıtlamıştır (Mahoney, 2001: 18-20).

Liberalleşme izleği, belli devlet kurumlarının nasıl örgütlendiğini belirlemiş, liberalleşme ve bu devlet kurumları yapısal direnç aşamasında döngüsel bir nedensellik içinde birbirini yeniden üretmiştir. Guatemala'da ordunun rolü kırsal kutuplaşmayı, kutuplaşma ise zor kullanma ihtiyacını güçlendirmiştir. 1890'da kahveye bağımlı devlet bütçesinin \%60'ını tüketen ordu, kırsal kesimde işgücü ihtiyacını zor kullanarak sağlamıştır. Şili'de kırsal kesim kutuplaşmış olmasına ve yüksek düzeyde zor kullanılmasına rağmen demokratikleşme gerçekleşmişti. Fakat, Şili'yi Guatemala ve El Salvador'dan ayıran fark, 1920'lere kadar giderek artan askerileşmeydi. Guatemala'da, 1954'ten itibaren kırsal gerilla hareketine dönüşen kırsal kutuplaşmanın askeri hükümetler tarafından bastırılması, 19. yüzyıldan 1986'da demokrasiye geçişe dek bu zor ilişkisinin neredeyse bir yüzyıl devam etmesi, döngüsel nedenselliğe işaret eder. Tek başına oligarşik üretim ilişkileri, her ikisi radikal liberalleşme deneyimlemesine rağmen, neden Guatemala'da 1940'ların sonunda demokratik reformlar yapılırken El Salvador'da askeri rejime geçildiğini

16 Vaka analizlerinde gerek-şart ve karşı-olgusal düşünmeyi etraflıca tartışan bir çalışma için bkz. Goertz ve Levy, 2007. 
açıklayamaz. Aradaki fark, kırılma noktasından sonraki süreçte ordu özerkliğindeki farklarla ilgilidir. Kosta Rika'da da devletin nasıl örgütlendiği ve bir devlet kurumu olarak ordunun rolü açıklayıcıdır. 1953'te demokrasiye geçişten önce kırsal kesimde küçük işletmeciliğin ve toprak dağılımının giderek küçülmesi ve parçalanması ciddi zorluklara yol açsa da ordu aracılığıyla zor kullanılmamış, demokratikleşme gerçekleşmiştir. Kırsal toprakların parçalanmasının 20. yüzyılın ortalarından sonlarına kadar sürmesine rağmen demokrasiyi engellememesi Kosta Rika'da izlek bağımlığını teyit eden bir unsurdur (Mahoney, 2001: 131).

\section{Sonuç}

Bu makale, süreç takibi yöntemini incelemek suretiyle, bu analitik aracın çıkarımsal faydalarından yararlanılmasına, dolayısıyla vaka analizlerinin kuramsal etkisinin belirginleştirilmesine ve artırılmasına katkı sağlamayı hedeflemiştir. Bu yöntemin çıkarımsal avantajları vaka analizlerinin kuram geliştirme işleviyle yakından ilgilidir. Karşılaştırmalı siyaset literatüründeki kuramlara göz atarsak, kuram geliştirme işlevini genelde vaka analizlerinin üstlendiğini görürüz. Vaka analizleri, korelasyonel mantığa dayanan istatistiksel çalışmalara kıyasla, yapı-yapan ilişkisinin nasıl geliştiğini mikro düzeyde tümevarımla gözlemlemeye hep daha yatkın olmuştur. Bu yüzden, yöntemin çıkarımsal faydaları arasında en önemlisi gerek nedenselliğin tayininde gerek nedenselliğin türü ve yönünün belirlemesinde nicel yöntemlerin eksiklerini gidermeye yardımcı olmasıdır. Süreç takibi ampirik açıdan zengin kanıtlara dayalı vaka analizlerine ihtiyaç duyar. Dolayısıyla, kuram geliştirme ve test olmadan da betimleyici vaka analizleri verdikleri kapsamlı ve derin bilgi itibariyle değerlidir. Bu yöntemle nedensel mekanizmaların tespit edilmesi ve testi sahte ilişkilere dayalı hipotezlerin elenmesine yardımcı olur. Yapı-yapan ilişkisinde tümevarımsal yolla nedenselliğin ve zamansallığın incelenmesi, içselliğin tespit edilmesini, göz ardı edilmiş olan bir değişkenin kurama dahil edilmesini sağlayabilir.

Nitel yöntemin küme kuramı mantığına dayalı nedensellik anlayışı üzerinden süreç takibini yeniden düşünmek çıkarımsal faydalarını ön plana çıkarmıştır. Süreç takibi eş-sonuçluluk, farklı nedenlerin veya nedensel izleklerin sonuca götürmesi ihtimalini göz önünde bulundurarak avantaj sağlar. Hipotezlerin yanlışlanabilirliğine dayalı Popperci anlayış süreç takibi testlerinde sistemleşmiş bir karşılık bulur. Bayesci mantık alternatif açıklamaların hangi kriterlere göre test edileceğine dair prosedürleri standartlaştırır. 
Bu çalışmada, en sık kullanılan halka ve dumanı tüten silah test teknikleri uygulamalı olarak gösterilmiştir.

Sosyal bilimlerde her yöntem gibi, süreç takibi de yöntemsel dezavantajlardan azade değildir. İlk olarak, süreç takibi diğer yöntemlere göre daha fazla zaman talep eder, çünkü hem kuramları ve alternatif açıklamaları hem ampirik verileri ve tarihsel arka planı detaylı bir şekilde, mikro ve makro düzeyde araştırmak gerekir. İkinci olarak, kuramlar genel hipotezler içeriyorsa ya da bilimsel çalışmalar nedenle sonuç arasındaki mantıksal ilişkileri net olarak aktarmamışsa, neyin gözlemleneceğini kestirmek güçleşir. Bu yüzden, analitik araç ve tekniklerin farkındalıkla ve sistemli kullanılması, bilimsel araştırmaya uzun vadede olumlu zincir etkide bulunacaktır. Üçüncü olarak, kanıtlar hipotezi yeteri kadar güçlü desteklemeyebilir. Bu durumda, nedensel ilişki hakkında kesinlik olmadığını tespit etmek de değerli bir katkıdır. Son olarak, genelleme yapmadan önce, kapsam koşullarını dikkate almak gerekir (Bennett ve Checkel, 2015: 23-31). Nitel vaka analizlerinin, özellikle tek vaka ve az-S vaka incelemesinin genelleme yapmak için yetersiz olduğu öne sürülmüş̧ür. Ancak istatistiksel genelleme araştırma evrenine uygulanırken nitel vaka analizinde bu mantık uygulanmaz. Süreç takibiyle vaka üzerinden tümevarımsal yolla geliştirilen kuramların genelleme gücü kapsam koşullarına bağlıdır. Bir kuramın kapsam koşulları ya da kapsama alanı nedir diye sormak onun genelleştirme sınırlarını sormaktır. Ayrıca, küme kuramı üzerinden genelleme gerekli ve yeterli şartlar prensipleri kullanılarak yapılır.

Vaka analizlerinin kuramsal etkisinin belirginleştirilmesine ve artırılmasına katkı sağlaması nedeniyle, süreç takibi yöntemin çoklu veya karma yöntem çalışmalarında payı giderek artmaktadır. Nicel araştırmalarda formel modellerin testi ve bu modellerin nedensel çıkarımlarının değerlendirilmesinde de süreç takibinin kullanılması mümkündür, nitelden nicele giderek süreç takibi ile kuram geliştirdikten sonra nicel araştırma yapılabilir ya da nicel ve nitel analiz birlikte yapılarak bir karşılaştırmaya gidilebilir. Araştırmacılar süreç takibini çoklu veya karma yöntemde kullanmadan önce farklı nedensellik yaklaşımları, nicel ve nitel kültürün dayandığı epistemolojik ve ontolojik temelleri göz önünde bulundurmalıdır. Bu konuda kavramsallaştırmadan vaka seçimine, kuram geliştirmeden ölçüme ve kuram testine uzanan yelpazede uygulamalı yöntembilimsel literatürün kapsamının genişlemesi ve çeşitlenmesi olumlu bir gelişmedir. 


\section{Kaynakça}

Acemoğlu, Daron, Suresh Naidu, Pascual Restrepo, James A. Robinson (2019). Democracy Does Cause Growth. Journal of Political Economy, 127(1), 47-100.

Aktürk, Şener, ve Lika, Idlir (2020). The puzzle of Turkish minority representation, nationhood cleavage, and politics of recognition in Bulgaria, Greece, and North Macedonia. Mediterranean Politics, Erken yayın, 1-28. https://doi.org/10.1080/13629395.2020.17 50269.

Bennett, Andrew (2015) Appendix: Disciplining Our Conjectures: Systematizing Process Tracing with Bayesian Analysis. Andrew Bennett ve Jeffrey T. Checkel (Ed.). Process Tracing. Process Tracing: From Metaphor to Analytic Tool (ss. 276-298). Cambridge: Cambridge University Press.

Bennett, Andrew, ve Checkel, Jeffrey T. (2015) Process Tracing: From Philosophical Roots to Best Practice. Andrew Bennett ve Jeffrey T. Checkel. (2015). Process Tracing. Process Tracing: From Metaphor to Analytic Tool (ss. 3-38). Cambridge: Cambridge University Press.

Bennett, Andrew, ve Elman, Colin. (2006). Qualitative Research: Recent Developments in Case Study Methods. Annual Review of Political Science, 9(1), 455-476.

Boix, Charles, ve Stokes, Susan C. (2003). Endogenous democratization. World Politics, 55(4), 517-549.

Bozçağa, Tuğba, ve Holland, Alisha C. (2018). Enforcement Process Tracing: Forbearance and Dilution in Urban Colombia and Turkey. Studies in Comparative International Development, 53(3), 300-323.

Brady, Henry E. (2008). Causation and Explanation in Social Science. Janet M. Box-Steffensmeier, Henry E. Brady, ve David Collier (Ed.), The Oxford Handbook of Political Methodology (ss. 217-270). Oxford, New York: Oxford University Press.

Braumoeller, Bear F. (2003). Causal Complexity and the Study of Politics. Political Analysis, $11(03), 209-233$.

Braumoeller, Bear F. (2004). Hypothesis testing and multiplicative interaction terms. International Organization, 58, 807-20.

Burkhart, Ross E., ve Lewis-Beck, Michael S. (1994). Comparative Democracy: The Economic Development Thesis. American Political Science Review, 88(4), 903-910.

Cansun, Şebnem, ve Arık, Engin (2019). Türkiye Adresli Siyaset Bilimi Yayınlarının Bibliyometrik Analizi. Ankara Üniversitesi SBF Dergisi, 47(3), 853-874.

Capoccia, Giovanni, ve Ziblatt, Daniel (2010). The historical turn in democratization studies: A new research agenda for Europe and beyond. Comparative Political Studies.

Clarke, Killian (2018). When do the dispossessed protest? Informal leadership and mobilization in Syrian refugee camps. Perspectives on Politics, 16(3), 617-633.

Collier, David (2011). Understanding process tracing. Political Science and Politics, 44(4), 823-830.

Collier, David, Henry E. Brady, Jason Seawright (2010). Sources of Leverage in Causal Inference: Toward an Alternative View of Methodology. Henry E. Brady ve David Collier (Ed.), Rethinking Social Inquiry: Diverse Tools, Shared Standards (ss. 161-200). Lanham, Boulder, New York, Toronto, Plymouth, UK: Rowman ve Littlefield Publishers.

Doner, Richard F., Brian K. Ritchie, Dan Slater (2005). Systemic vulnerability and the origins of developmental states: Northeast and Southeast Asia in comparative perspective. International Organization, 59(2), 327-361. 
Doyle, Arthur Conan (2012). The Complete Sherlock Holmes. New York: Doubleday.

English, Robert (2007). Perestroika without politics: How realism misunderstands the Cold War's end. Gary Goertz ve Jack S. Levy (Ed.), Explaining war and peace: Case studies and necessary condition counterfactuals (ss. 237-260). Londra ve New York: Routledge.

George, Alexander L. (1979). Case Studies and Theory Development: The Method of Structured, Focused Comparison. Paul G. Lauren (Ed.), Diplomacy: New Approaches in History, Theory and Policy (ss. 43-68). New York: The Free Press.

George, Alexander L., ve Bennett, Andrew (2005). Case Studies and Theory Development in the Social Sciences. Cambridge, Mass.: MIT Press.

Gerring, John (2004). What Is a Case Study and What Is It Good for? The American Political Science Review, 98(2), 341-354.

Goertz, Gary (2006). Social Science Concepts: A User's Guide. Princeton ve Oxford: Princeton University Press.

Goertz, Gary, ve Levy, Jack S.(2007). Explaining War and Peace: Case Studies and Necessary Condition Counterfactuals. Londra ve New York: Routledge.

Goertz, Gary, ve Mahoney, James (2012). A Tale of Two Cultures: Qualitative and Quantitative Research in the Social Sciences. Princeton ve Oxford: Princeton University Press.

Hall, Peter A. (2003). Aligning ontology and methodology in comparative research. James Mahoney ve Dietrich Rueschemeyer (Ed.), Comparative Historical Analysis in the Social Sciences (ss. 373-404). Cambridge, Mass.: Cambridge University Press.

Hall, Peter A. (2008). Systematic Process Analysis: What it is and how to use it. European Political Science, 7(3), 304-17.

Hume, David ([1748] 2004). Enquiries Concerning Human Understanding. New York: Dover Publications.

İşeri, Emre, ve Esentürk, Nevra (2016). Türkiye'de Uluslararası İlișkiler Çalıșmaları: Merkez-Çevre Yaklaşımı. Elektronik Mesleki Gelişim ve Araştırma Dergisi, 6(2), 17-33.

King, Gary, Robert O.Keohane, Sidney Verba (1994). Designing Social Inquiry: Scientific Inference in Qualitative Research. Princeton, New Jersey: Princeton University Press.

Lipset, Seymour Martin (1959). Some Social Requisites of Democracy: Economic Development and Political Legitimacy, The American Political Science Review, 53(1), 69-105.

Mackie, John L. (1965). Causes and Conditions. American Philosophical Quarterly, 2, 245-264.

Mahoney, James (2001). The Legacies of Liberalism: Path Dependence and Political Regimes in Central America. Latin American Politics and Society. Baltimore. MD: The Johns Hopkins University Press.

Mahoney, James (2012). The Logic of Process Tracing Tests in the Social Sciences. Sociological Methods and Research, 41(4), 570-597.

Mahoney, James (2015). Process Tracing and Historical Explanation. Security Studies, 24(2), 200-218.

Mahoney, James (2016). Mechanisms, Bayesianism, and process tracing. New Political Economy, 21(5), 493-499.

Mahoney, James, ve Falleti, Tulia G. (2015). The comparative sequential method. James Mahoney ve Kathleen Thelen (Ed.), Advances in Comparative Historical Analysis (ss. 211-239). New York: Cambridge University Press.

Mahoney, James, ve Vanderpoel, Rachel S. (2015). Set Diagrams and Qualitative Research. Comparative Political Studies, 48(1), 65-100. 
Mainwaring, Scott, ve Pérez-Linán, Aníbal (2013). Democracies and Dictatorships in Latin America: Emergence, Survival, and Fall. New York: Cambridge University Press.

Mello, Patrick A. (2014). Democratic Participation in Armed Conflict. Houndmills: Palgrave Macmillan.

Mill, John Stuart (1843). A System of Logic. Toronto: University of Toronto Press.

Mumford, Stephen, ve Anjum, Rani Lill (2013). Causation: A Very Short Introduction. Oxford, UK: Oxford University Press.

Munck, Gerardo L., ve Snyder, Richard (2007). Debating the direction of comparative politics: An analysis of leading journals. Comparative Political Studies, 40(1), 5-31.

Pierson, Paul (2011). Politics in time: History, institutions, and social analysis. Politics in Time: History, Institutions, and Social Analysis. Princeton, New Jersey: Princeton University Press.

Popper, Karl (1969). Conjectures and Refutations. London: Routledge and Kegan Paul.

Price, Richard (1763) An essay towards solving a problem in the doctrine of chances. Philosophical Transactions of the Royal Society, Cilt LIII, 53, 370-418.

Przeworski, Adam, Michael Alvarez, Jose A. Cheibub, Fernando Limongi (2000). Democracy and Development: Political Institutions and Material Wellbeing in the World (1950-1990). Cambridge: Cambridge University Press.

Ragin, Charles C. (1987). The Comparative Method: Moving Beyond Qualitative and Quantitative Strategies. Berkeley: The University of California Press.

Ragin, Charles C. (1992). Introduction: Cases of "What is a case?" (ss. 1-18). Cambridge University Press.

Rueschemeyer, Dietrich, John D. Stephens, Evelyn H. Stephens (1992). Capitalist Development and Democracy. Chicago: University of Chicago Press.

Sartori, G. (1970). Concept Misformation in Comparative Politics. American Political Science Review, 64(04), 1033-1053.

Sekhon, Jasjeed S. (2010). The Neyman-Rubin-Holland Model of Causal Inference and Estimation via Matching Methods. Janet M. Box-Steffensmeier, Henry E. Brady, ve David Collier (Ed.), The Oxford Handbook of Political Methodology (ss. 271-299). Oxford University Press.

Somer, Murat (2014). Theory-consuming or Theory-producing?: Studying Turkey as a Theory-developing Critical Case. Turkish Studies, 15(4), 571-588.

Söyler, Mehtap (2020a). Kavram ve Kuram Analizi Yöntemi: Sartori Geleneği. Uluslararası ilişkiler, 66(17), 93-115.

Söyler, Mehtap (2020b). Nitel ve Nicel Yöntem Farkına Çoğulcu Yaklaşım: KKV-Sonrası Dönemde Nitel Yöntem ve Kazanımları. Amme Idaresi Dergisi, 53(2), 99-127.

Taydaş, Zeynep, ve Özdamar, Özgür. (2013). A Divided Government, an Ideological Parliament, and an Insecure Leader: Turkey's Indecision about Joining the Iraq War. Social Science Quarterly, 94(1), 217-241.

Trampusch, Christine, ve Palier, Bruno (2016). Between $X$ and $Y$ : how process tracing contributes to opening the black box of causality. New Political Economy, 21(5), 437-454.

Van Evera, Stephen (1997). Guide to methods for students of political science. Ithaca, NY: Cornell University Press.

Waldner, David (2015). What Makes Process Tracing Good? Causal Mechanisms, Causal Inference, and the Completeness Standard in Comparative Politics. Andrew Bennett ve Jeffrey T. Checkel (Ed.), Process Tracing: From Metaphor to Analytic Tool (ss. 126-152). Cambridge: Cambridge University Press. 